Available online at : http://journal.unj.ac.id/unj/index.php/gjik

Gladi : Jurnal Ilmu Keolahragaan 12 (03) Special Issue 2021, 39-44

Permalink/DOI: https://doi.org/10.21009/GJIK.123.06

\title{
THE EFFECTIVENESS OF MIX IMPACT AEROBIC GYMNASTICS EXERCISES WITH SKJ 2000 ON IMPROVEMENT OF PHYSICAL FRESHNESS
}

\author{
Anik Maryani ${ }^{1}$, Fahmy Fachrezzy $^{1}$, Ramdan Pelana $^{1}$ \\ ${ }^{1}$ Physical Education, Graduate Program, Jakarta State University, Jakarta Indonesia \\ Correspondiing author. Email : AnikMaryani_9903820030@mhs.unj.ac.id
}

\begin{abstract}
Abstrak This study aims to determine the effectiveness of the effect of aerobic mix impact and SKJ 2000 version (core exercise) to improve physical fitness in female students. The research was conducted at SMEA YASMA Sudirman Cijantung for 8 weeks with 24 meetings. The method used is an experimental method with a pre and post-test design. The sampling technique was random sampling from a total of 40 grade 1 students and 30 samples were taken. The data collection technique used was a physical fitness test using the Indonesian Physical Fitness Test (TKJI). Hypothesis testing uses the t-test at the significant level $(\alpha) 0.05$. The results showed that the difference between the mean value of the initial test $(\mathrm{x})$ and the final test $(y)$ in the mixed impact aerobic exercise group was obtained $=-6.47$; the value of the standard deviation of the difference $=1,2$; the standard error value of the mean difference $=0.32$; and the value becomes $=-20,2$. The initial test $(\mathrm{x})$ and the final test $(\mathrm{y})$ in the 2000 version of the Physical Fitness exercise obtained the difference in the mean value is $=-5$; the value of the standard deviation of the difference $=1.1$; the standard error value of the mean difference $=0.29$; and the value becomes $=-17.24$. The final test of the mixed impact aerobic exercise group (x) and the final test of the aerobic exercise group (y) version 2000, obtained the mean value of the variable $\mathrm{x}=19.33$; variable value $\mathrm{y}=17$; the standard deviation value $\mathrm{x}=1.48$; standard deviation of the variable $\mathrm{y}=2.31$; standard error variable $\mathrm{x}=$ 0.4 ; standard error for the variable $\mathrm{y}=0.62$; standard error for the mean difference between $\mathrm{x}$ and variable $=0.74$; Hypothesis test results obtained t observation $=3.15$, at 28 degrees of freedom and a significant level $(\alpha) 0.05$, the value of $t$ table $=2.048$ is obtained. The conclusion of the study is that the effect of mix impact aerobic exercise is more effective in improving physical fitness compared to those using the 2000 version of the fitness gymnastics version of aerobic exercise.
\end{abstract}

Key Words: Mix impact aerobic exercise, SKJ 2000 version one, physical fitness 


\section{INTRODUCTION}

Physical fitness is the main asset of everyone, if you are not fit you cannot do physical activity, physical fitness has an important role in life, if you are not healthy you cannot do other activities. According to Sutarman in Arsil (2009: 9) "physical fitness is an aspect, namely the physical aspect of total fitness which gives a person the ability to live a productive life and be able to adjust to each physical stress. ) worthy". (Hardiansyah, 2017). With a physically fit condition, it allows a person to be able to work productively and efficiently, learning more enthusiastically can achieve optimally. According to Azizi Fikri's opinion, physical fitness is a person's ability to carry out his daily duties easily, without feeling too tired and having the remaining or spare energy to enjoy his spare time and for sudden needs. Physical fitness is a very important potential in supporting daily activities days without feeling excessively tired and even able to carry out activities afterwards. Through directed and continuous physical activity, it will have an impact on physical health and health. With a physically fit condition, it allows a person to be able to work productively and efficiently, learning more enthusiastically can achieve optimally. Meanwhile, in another opinion, physical fitness is a very important potential in supporting daily activities without feeling excessive fatigue and even being able to carry out activities afterwards. Through directed and continuous physical activities, it will have an impact on physical fitness and health (Abduh et al., 2020).

Aerobic exercise, which is currently endemic among the public, is one way of exercising to improve physical fitness and health, including new types of exercise movements such as: low impact, mix impact, high impact, yoga, zumba and SKJ gymnastics which are always updated according to developments. era. Aerobic exercise is an exercise that combines various kinds of movements, rhythmic, regular and directed, as well as a cheerful nature (Endang Rini Sukamti, 2016). Aerobic exercise has a balanced and systematic exercise arrangement between upper body and lower body exercises. Meanwhile, Jonni (2003: 4) argues that aerobic exercise is an exercise done to burn fat while improving muscle tone, which is led by experienced trainers together accompanied by music that is in accordance with the rhythm / movement of the moving limbs. (Indah, 2016). Because it is accompanied by music, it creates a joyful and pleasant atmosphere besides that it has the benefit of obtaining the desired ideal body shape. Physical Fitness Gymnastics or better known as SKJ is included in cheap and easy to do gymnastics. Physical Fitness Gymnastics (SKJ) continues to develop until now several forms of gymnastics have emerged according to the times. Physical Fitness Gymnastics (SKJ) is an effective physical activity to optimize children's growth and development (Altaibi1 a), Armade, M2, and Manurizal, 2020). Physical Fitness Gymnastics (SKJ) also has the potential to improve the fitness of students, so that it affects student learning outcomes. Aerobic exercise has many types of variations, of which the author tries to examine the types of mix impact aerobic exercise. This gymnastics exercise is a combination of low impact and high impact exercises that are popular with many people because the movements are varied so that the person doing this exercise is not boring and the intensity is moderate, the music that 
accompanies it is also varied, interesting and motivates someone to move. Apart from aerobics, Indonesia has long been known as Physical Fitness Gymnastics (SKJ). This Physical Fitness Gymnastics has many versions, starting from the 1984, 1988, 1992, 1996, 2000,2004,2008,2012,2018 versions, and finally the physical fitness gymnastics 2020. From each version there are always changes and improvements both in intensity and movement movements. the rhythm of the movement, the musical accompaniment is interesting and varies from regional songs, all of which are done to further improve one's physical fitness.

Mix impact aerobic exercise is more effective in increasing the physical fitness of students because the movements and accompaniments of songs or music are very varied, so that they are not boring. Students perform happily, happily, enthusiastically, energetically, because the movements are easy to follow, effective and efficient. Aerobic exercise increases the physical fitness of students if it is done with the right rules, good physical fitness can increase academic achievement.

Physical education can shape and improve positive physical and mental qualities for students and have an important role in national life. Aerobic mix impact gymnastics is one of the exercises that must be done for teachers and students every Friday at 6:30 a.m., this exercise is led by a sports teacher, and is always carried out in a varied way so that students don't get bored.

\section{METHODS}

This study uses an experimental method with pre and post test design.
This research is a type of preexperimental research (One-Group Pretest-Posttest design). (Risal, nd) is to determine the effect of the physical fitness level of students who do aerobic mix impact exercise. and 2000 version one of gymnastics for female students of SMK 2 Sudirman Cijantung, East Jakarta.

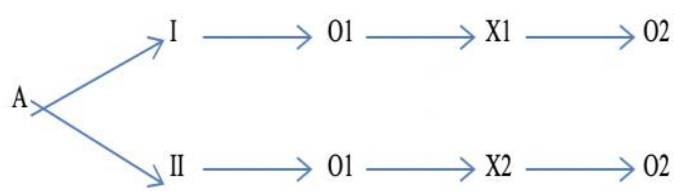

Figure 1. Descriptive Analysis Result

Information :

$\mathrm{A}=$ Random

$\mathrm{I}=$ Mic Impact aerobic group

II = Group of 2000 core exercises for physical fitness

$\mathrm{O} 1=$ Pre Test

$\mathrm{X} 1$ = Mix Impact aerobic exercise

$\mathrm{X} 2$ = Physical fitness exercises 2000 core exercises Version 1

$\mathrm{O} 2=$ Post Test

\section{Participants}

This research was conducted at SMEA Sudirman Cijantung, Pasar Rebo sub-district, East Jakarta. The population in this study were students of class X SMK 2 Sudirman.

The sampling technique in this study was taken with a probability sampling method, namely the Simple Random Sampling method (Acharya et al, 2013) with random sampling so that all elements in the population have the same opportunity to be taken as a sample representing the population and the sample will be taken. based on student serial number ramdomisasi.

\section{Instrument}

The data collection
instrument in this study was the 
Indonesian Physical Fitness Test (TKJI) method (Nurcahyo, Eko \& Nasution, 2014). Physical fitness test for female students, a. 60 meters run, b. Hang sitting elbows, c. Lie down for 60 seconds, d. Jump upright, e. Run far 1000 meters.

Data collection technique

1. Crude Results.

The performance of each test that a child achieves in taking the test is called a rough result. The level of physical fitness of a child cannot be assessed directly based on the achievements achieved, because the unit of measure used for each test is not the same.

2. Test scores.

The rough results, which are still different units of measure, are replaced with the same unit of measure. The replacement unit of measure is the value, after changing the value of the five test results, they are added by looking at the value table and the norm table. The sum results are the basis for determining the classification of the child's physical fitness.

\section{RESULTS}

The analysis technique in this study used the t-test statistical technique A.The " $\mathrm{t}$ " test is for two small, interconnected samples

1. If $\mathrm{t} 0 \geq \mathrm{t}$ table at $\alpha 0.05, \mathrm{H} 0$ is rejected, otherwise Ha is accepted.

This means that between the two variables has a significant difference.

2. $\mathrm{t} 0<\mathrm{t}$ table at $\alpha 0.05, \mathrm{H} 0$ is accepted, otherwise $\mathrm{Ha}$ is rejected. This means that the difference between the two variables is not a significant difference.

B. The " $t$ " test for two small samples that are unrelated to each other.

1. If $\mathrm{t} 0 \geq \mathrm{t}$ table at $\alpha 0.05, \mathrm{H} 0$ is rejected, otherwise $\mathrm{Ha}$ is accepted.
This means that there is a significant difference between the two variables.

2. t0 $<\mathrm{t}$ table at $\alpha 0.05, \mathrm{H} 0$ is accepted, otherwise $\mathrm{Ha}$ is rejected

There is a significant difference between the final test results of the Mix Impact aerobic exercise group and 2000 version one of the physical fitness training group. This means that the Mix Impact aerobic exercise is more effective than the 2000 version one fitness exercise in an effort to improve the physical fitness of the $\mathrm{X}$ grade students of SMK 2 Sudirman.

Statistical analysis The subjects of this study were students at SMK 2 Sudirman. From a total of 40 students, made sheets of paper according to the names of 40, then 30 names were taken randomly, these names were sampled. Of the 30 samples, an initial physical fitness test was held using the Indonesian high school age physical fitness test (TKJI). The tests were arranged according to ranks 1 to 30 then divided into two groups, odd and even groups, the odd group got mixed impact training, while the even group got 2000 version one core exercise.

\section{Table 1.}

Single distribution of Pre test of physical fitness gymnastic 2000 version one

\begin{tabular}{|c|c|c|c|}
\hline No & Nilai & Batas Nyata & Frekuensi \\
\hline 1 & 8 & $7,5-8,5$ & 1 \\
2 & 9 & $8,5-9,5$ & 1 \\
3 & 7 & $9,5-10,5$ & 1 \\
4 & 11 & $10,5-11,5$ & 4 \\
5 & 12 & $11,5-12,5$ & 1 \\
6 & 13 & $12,5-13,5$ & 3 \\
7 & 14 & $13,5-14,5$ & 2 \\
8 & 15 & $14,5-15,5$ & 2 \\
\hline \multicolumn{2}{|r|}{ Jumlah } & 15 \\
\hline
\end{tabular}

The following diagram is a single histogram diagram for the pre test of the physical fitness gymnastic 2000 version one. 


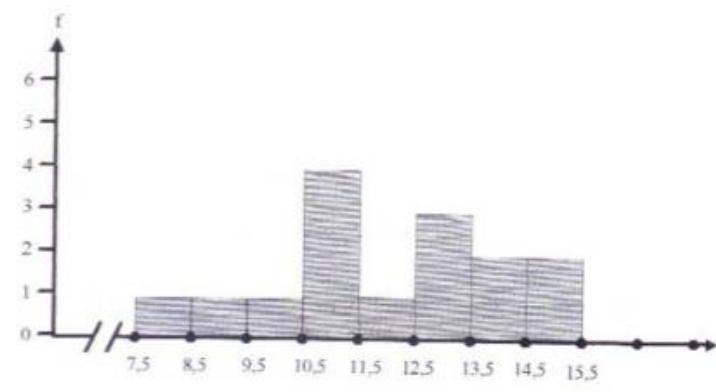

Figure 1. Single distribution of Pre test of physical fitness gymnastic 2000 version one

Table of Singgle distribution of post test of physical fitness aerobics mix impact and physical fitness gymnastic 2000

\section{Table 2.}

Singgle distribution of post test of physical fitness aerobics mix impact

\begin{tabular}{|c|c|c|c|}
\hline No & Tes awal & Batas Nyata & Frekuensi Absolut \\
\hline 1 & 18 & $17,5-18,5$ & 4 \\
2 & 19 & $18,5-19,5$ & 7 \\
3 & 20 & $19,5-20,5$ & 2 \\
4 & 21 & $20,5-21,5$ & 1 \\
5 & 22 & $21,5-22,5$ & 0 \\
6 & 23 & $22,5-23,5$ & 0 \\
7 & 24 & $23,5-24,5$ & 1 \\
\hline \multicolumn{4}{|c|}{ Jumlah } \\
\hline
\end{tabular}

The following diagram is a comparison histogram diagram for the post test of aerobic mix impact

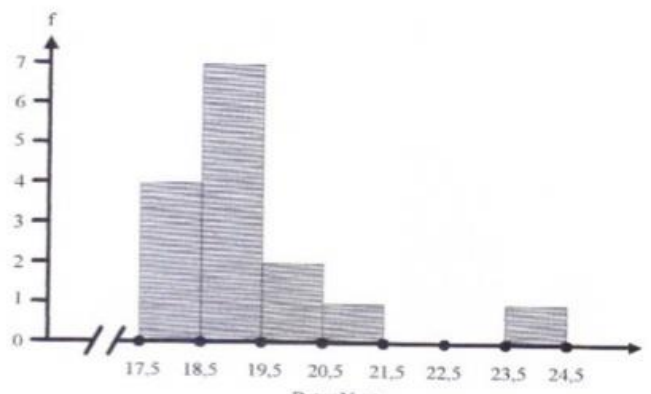

Figure 2. Histogram diagram for the post test of aerobic mix impact

Table 3.

Single distribution physical fitness Gymnastic post test 2000 version one

\begin{tabular}{|c|c|c|c|}
\hline No & Nilai & Batas Nyata & Frekuensi Absolut \\
\hline 1 & 11 & $10,5-11,5$ & 1 \\
2 & 12 & $11,5-12,5$ & 0 \\
3 & 13 & $12,5-13,5$ & 0 \\
4 & 14 & $13,5-14,5$ & 2 \\
5 & 15 & $14,5-15,5$ & 0 \\
6 & 16 & $15,5-16,5$ & 0 \\
7 & 17 & $16,5-17,5$ & 5 \\
8 & 18 & $17,5-18,5$ & 4 \\
9 & 19 & $18,5-19,5$ & 1 \\
10 & 20 & $19,5-20,5$ & 2 \\
\hline \multicolumn{7}{|c|}{ Jumlah } \\
\hline \multicolumn{7}{|c|}{ following figure is a } \\
\hline
\end{tabular}

histogram diagram of a post-test comparison of physical fitness gymnastic 2000 version one.

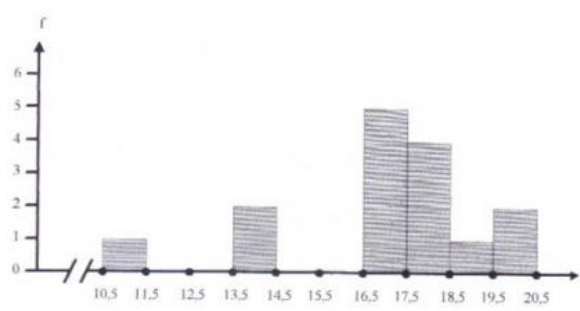

Figure 3. Histogram diagram of a posttest comparison of physical fitness gymnastic 2000 version one

\section{Discussion}

In this study, it was proven that the mix impact aerobic exercise was proven to be effective in increasing physical fitness for class $\mathrm{X}$ students of SMK 2 Sudirman. The things that are recommended from the results of this study are:

1. For research subjects

With the better the level of physical fitness of students and students can increase academic achievement.

2. For schools

For physical education teachers and principals to pay more attention in calculating lesson hours, especially physical education.

\section{CONCLUSIONS}

From the results of the research that has been done, it can be concluded that the aerobic mix impact exercise is more effective than 2000 version one of the physical fitness exercise in 
improving physical fitness in class $\mathrm{X}$ SMK 2 Sudirman.

\section{REFERENCES}

Abduh, I., Agusman, M., \& Tadulako, U. (2020). Analisis Hubungan Tingkat Kesegaran Jasmani terhadap Hasil Belajar Siswa. JOSSAE (Journal of Sport Science and Education), 5(2), 75-82.

Endang Rini Sukamti, M. I. Z. R. B. (2016). Profil Kebugaran Jasmani Dan Status Kesehatan Instruktur Senam Aerobik Di Yogyakarta. Jurnal Olahraga Prestasi, 12(2), 116313. https://doi.org/10.21831/jorpres. v12i2.11875

Hardiansyah, S. (2017). Pengaruh Metode Interval Training Terhadap Peningkatan Kesegaran Jasmani Mahasiswa Jurusan Pendidikan Olahraga. Jurnal PENJAKORA, 4(September), 83-92. https://ejournal.undiksha.ac.id/in dex.php/PENJAKORA/article/vi ewFile/13369/8401

Indah, D. (2016). PENGARUH LATIHAN SENAM AEROBIK TERHADAP PENURUNAN KADAR LEMAK TUBUH ANGGOTA SENAM SANGGAR KEBUGARAN MUSLIMAH CENTRE PADANG. Journal of Chemical Information and Modeling, 53(9), 1689-1699.

Nurcahyo, Eko \& Nasution, J. D. H. (2014). Survei Tingkat Kesegaran Jasmani Siswa Kelas XI (Sebelas) SMA Muhammadiyah 1 Babat Kabupaten Lamongan. Jurnal Pendidikan Olahraga Dan Kesehatan, 2(1), 88-93.
Risal, S. (n.d.). Pengaruh Latihan Intensitas Tinggi Terhadap Kadar Glukosa Darah Pada Tim Sepak Bola SMA nEGERI 5 Pinrang. 330-341.

Siyam, Syarifah Nur LailiSiyam, S. N. L., Nurhapsari, A., \& Benyamin, B. (2015). Pengaruh Stimulasi Permainan Ular Tangga Tentang Gingivitis

Terhadap Pengetahuan Anak Usia 8-11 Tahun. ODONTO Dental Journal, 2 (1), 25-28., Nurhapsari, A., \& Benyamin, B. (2015). Pengaruh Stimulasi Permainan Ular Tangga Tentang Gingivitis Terhadap Pengetahuan Anak Usia 8-11 Tahun. ODONTO Dental Journal, 2 (1), 25-28. 